\title{
KENAKALAN REMAJA DAN PENANGANANNYA
}

\author{
Fahrul Rulmuzu \\ Email: fahrulmauzu@gmail.com
}

\begin{abstract}
Abstrak. Berbicara tentang remaja memang sangat menarik karena remaja adalah genrasi penerus agama dan bangsa, keselamatan bangsan kedepan terletak ditangan para remaja masa kini. Remaja merupakan aset masa depan suatu bangsa, Namun saat ini banyak sekali yang terjadi pada diri remaja, seperti perkelahian, perampokan, narkoba genk motor, dan lain - lain. Hal ini merupakan masalah yang sudah tidak asing lagi. Kenakalan remaja meliputi semua perilaku yang menyimpang dari norma-norma hukum pidana yang dilakukan oleh remaja. Banyak sekali faktor internal dan eksternal penyebab kenakalan remaja yang perlu diperhatikan. Untuk mengatasinya maka bimbingan dari orang tua dan juga lingkungan yang baik bisa menjadi penentu bagi perkembangan remaja tersebut.
\end{abstract}

Kata kunci: kenakalan remaja, moral, perkembangan remaja

\section{PENDAHULUN}

Remaja adalah seorang yang berumur 12 sampai 18 tahun (Hasbullah, 1999:12). Remaja adalah masa peralihan dari kanakkanak ke dewasa. Pada masa ini akan selalu terjadi pertentangan antara orang tua dan remaja itu sendiri, namun apabila pada masa sebelumnya (anak - anak) hubungan antara orang tua dan anak telah dibina secara baik, pada umumnya remaja akan mampu mengikuti pendapat dan pandangan orang tuanya. Pada masa ini didalam diri para remaja terjadi pertentangan yangn disebut expolosive bipolarity karena anak merasa berdiri dengan sebelah kaki di lingkungan keluarga (ketergantungan) dan sebelah kakinya yang lain berada diluar keluarga (Terlepas dari ketergantungan). Kenyataan seperti itu sebenarnya menempatkan para remaja pada kondisi yang sangat membutuhkan bimbingan, baik dari orang tua maupun dari guru - gurunya di sekolah. Akan tetapi sikap menolak dan menghindar dari para remaja itu sendiri sering mempersulit upaya pemberian bimbingan dan petunjuk kepada mereka. Untuk itulah diperlukan langkah - langkah yang bijaksana dari para pendidik dalam melakukan pendekatan terhadap para remaja.

"Masa remaja merupakan masa peralihan dari anak-anak ke masa dewasa. Masa transisi ini seringkali menghadapakan individu yang bersangkutan kepada situasi yang membingungkan, disatu pihak masih kanak-kanak, tetapi dilain pihak ia sudah harus bertingkah laku seperti orang dewasa. Situasi-situasi yang menimbulkan konflik seperti ini, sering menyebabkan perilaku-perilaku yang aneh, canggung dan kalau tidak dikontrol bias menjadi kenakalan" (Sarwono, 2012:72).

Seorang remaja sudah tidak lagi dapat dikatakan sebagai kanak - kanak, namun ia masih belum cukup matang untuk dapat dikatakan dewasa. Ia sedang mencari pola hidup yang paling sesuai baginya dan ini pun sering dilakukan melalui metoda coba-coba walaupun melalui banyak kesalahan. Kesalahan yang dilakukannya sering menimbulkan kekuatiran serta perasaan yang tidak menyenangkan bagi lingkungannya, orang tuanya. Kesalahan yang diperbuat para remaja hanya akan menyenangkan teman sebayanya. Hal ini karena mereka semua memang sama-sama masih dalam masa mencari identitas. Kesalahan-kesalahan yang menimbulkan kekesalan lingkungan inilah yang sering disebut sebagai kenakalan remaja

Remaja merupakan aset masa depan suatu bangsa, keselamatan bangsa kedepan terletak di tangan para pemuda masa kini . Para pemuda dan remaja merupakan tumpuan masa depan manusia. Para pemuda dan remajalah yang mesti tampil mengusung harapan yang menggembirakan, generasi 
seperti itulah genersi harapan. Generasi harapan yang dimaksud adalah para pemuda dan remaja, karena para pemudalah yang mendominasi pasukan yang ikut berjihad bersama Rasulullah, sebagian besar penceramah dan singa podium dimasa rasulullah juga para pemuda dan remaja, para utusan dan ajudan rasulullah juga kawula muda. Remaja seperti inilah yang akan menjadi orangn - orang pilihan, menjadi pelita hidup dan menjadi panutan yang dibanggakan. Namun keadaan remaja kita saat sekarang bertolak belakang dengan remaja diatas. Ketika kita membahas remaja masa kini kita dihadapkan pada sebuah pandangan yang ironis. Remaja yang menjadi tumpuan masa depan bangsa mesti tampil sebagai pengusung harapan yang menggembirakan. Tapi kenyataan nya hari ini maoritas remaja kita terperosok dalam lumpur kesesatan, perkelahian, perampokan, narkoba genk motor, dan lain - lain menjadi warna yang melekat pada diri remaja saat ini, ditambah lagi sikap dan lingkungan yang kurang memperhatikan mereka seolah pelengkap keprihatinan ini. Dalam surat kabar surat kabar sering kali kita membaca berita tentang perkelahian pelajar, penyebaran narkotika, pemakaian obat bius, minuman keras, penjambret yang dilakukan oleh anak anak yang berusia belasan tahun, meningkatnya kasus-kasus kehamilan di kalangan remaja putri dan lain sebagainya. Hal tersebut adalah merupakan suatu masalah yang dihadapi masyarakat yang kini semakin marak, Kondisi remaja dengan gambaran tersebut membuat kita berpikir apa yang terjadi pada remaja kita dan mengapa mereka rusak ? hanya orang tua yang arif saja yang kiranya secara tepat dapat menyadari bahwa kesalahan semua itu bukan karena anak semata melainkan lebih besar karena didikan orang tua. Hal ini didukung oleh sebuah hadis nabi Muhammad saw yang artinya:

"Setiap bayi yang lahir dalam keadaan fitrah, maka orang tuanyalah yang menjadikan mereka yahudi, nasrani dan majusi”.

(H.R Bukhari)

Untuk itu peran orang tua mutlak diperlukan oleh remaja. Orang tua harus tetap memberikan bimbingan keagamaan pada remaja. Kondisi keluarga yang tidak harmonis, ataupun orang tua yang tidak memberikan kasih sayang yang utuh dan berteman dengan kelompok sebaya yang kurang yang kurang menghargai niali - nilai agama, maka remajapun akan bersikap kurang baik atau asusila misalnya free sex, minuman keras membuat onar, menghisap ganja dan sebagainya.

(Zuhdiyah, 2012:76).

Oleh karena itu masalah kenakalan remaja seyogyanya mendapatkan perhatian yang serius dan terfokus dari orang tua untuk mengarahkan remaja ke arah yang lebih positif, yang titik beratnya untuk terciptanya suatu sistem dalam menanggulangi kenakalan di kalangan remaja.

\section{METODE}

\section{Pengertian Kenakalan Remaja}

Setiap remaja memiliki lingkungan yang berbeda-beda serta latar belakang ekonomi yang berbeda beda, pergaulan, keluarga, pendidikan, dan seterusnya. Pergaulan yang salah menjadi salah satu penyebab terjadinya kenakalan remaja. Apalagi di zaman sekarang ini dengan alasan modernisasi para remaja ingin mencoba sesuatu yang seharusnya tak pantas dikerjakan. Misalnya enggunaan obat terlarang seperti narkoba, minum-minuman keras, pergaulan bebas, dan sebagainya. Apabila kenakalan remaja dibiarkan begitu saja, tentu akan merusak masa depan mereka sendiri, terlebih masa depan bangsa ini. Kenakalan remaja di era modem ini sudah melebihi Batas yang sewajamya. Banyak anak di bawah umur yang sudah mengenal rokok, narkoba, freesex, dan terlibat banyak tindakan kriminal lainnya. Fakta ini sudah tidak dapat dipungkuri lagi, kita dapat melihat brutalnya remaja zaman sekarang. Masalah kenakalan remaja dewasa ini semakin dirasakan masyarakat, baik di negara-negara maju maupun negara berkembang. Dalam kaitan ini, masyarakat Indonesia telah mulai pula merasakan. Keresahan tersebut, terutama mereka yang berdomisili di kota-kota besar. Akhir-akhir ini masalah tersebut cenderung menjadi masalah nasional yang dirasa 
semakin sulit untuk dihindari, ditanggulangi, dan diperbaiki kembali. Di beberapa media masa sering kita membaca tentang perbuatan kriminalitas yang terjadi di negeri yang kita cintai ini. Ada anak remaja yang meniduri ibu kandungnya sendiri, perkelahian antar pelajar, tawuran, dan masih banyak lagi kriminalitas yang terjadi di negeri ini. Kerusakan moral sudah merebak di seluruh lapisan masyarakat, mulai dari anak-anak sampai orang dewasa serta orang yang sudah lanjut usia. Termasuk yang tidak luput dari kerusakan moral ini adalah remaja. Para ahli pendidikan sependapat bahwa remaja adalah mereka yang berusia 13-18 tahun. Pada usia tersebut, seseorang sudah melampaui masa kanakkanak, namun masih belum cukup matang untuk dapat dikatakan dewasa. Ia berada pada masa transisi dan pencarian jati diri, yang karenanya sering melakukan perbuatan -perbuatan yang dikenal dengan istilah kenakalan remaja. Kenakalan remaja meliputi semua perilaku yang menyimpang dari norma-norma hukum pidana yang dilakukan oleh remaja. Perilaku tersebut akan merugikan dirinya sendiri dan orang-orang di sekitarnya. Kenakalan-kenakalan remaja saat ini semakin meningkat dan semakin beragam, namun pernahkah disadari bahwa kenakalankenakalan yang ditimbulkan remaja, bukan hanya tanggung jawab remaja itu sendiri, akan tetapi merupakan tanggung jawab orangorang di sekitar mereka. Masalah kenakalan remaja mulai mendapat perhatian masyarakat secara khusus sejak terbentuknya peradilan untuk anak-anak nakal (juvenilecourt) pada 1899 di Illinois, Amerika Serikat. Beberapa ahli mendefinisikan kenakalan remaja ini sebagai berikut:

1. Kartono, ilmuwan sosiologi

"Kenakalan Remaja atau dalam bahasa Inggris dikenal dengan istilah juvenile delinquency merupakan gejala patologis social pada remaja yang disebabkan oleh satu bentuk pengabaian sosial. Akibatnya, mereka mengembangkan bentuk perilaku yang menyimpang".

2. Santrock

"Kenakalan remaja merupakan kumpulan dari berbagai perilaku remaja yang tidak dapat diterima secara sosial hingga terjadi tindakan kriminal."

Willis (2012:90) berpendapat "kenakalan remaja ialah tindak perbuatan sebagian para remaja yang bertentangan dengan hukum, agama, dan norma - norma masyarakat, sehingga akibatnya dapat merugikan orang lain, mengganggu ketentraman umum dan juga merusak dirinya sendiri”.

\section{Penyebab Kenakalan Remaja}

Banyak faktor yang menjadi penyebab kenakalan remaja. Menurut Willis (2005: 93) kenakalan remaja disebabkan oleh empat faktor yaitu: faktor yang ada dalam diri anak sendiri, faktor yang berasal dari lingkungan keluarga, faktor yang berasal dari lingkungan masyarakat, dan yang terakhir yaitu faktor yang bersumber dari sekolah.

Ulah para remaja yang masih dalam tarap pencarian jati diri sering sekali mengusik ketenangan orang lain. Kenakalankenakalan ringan yang mengganggu ketentraman lingkungan sekitar seperti sering keluar malam dan menghabiskan waktunya hanya untuk hura-hura seperti minumminuman keras, menggunakan obat-obatan terlarang, berkelahi, berjudi, dan lain-lainnya itu akan merugikan dirinya sendiri, keluarga, dan orang lain yang ada disekitarnya. Cukup banyak faktor yang melatar belakangi terjadinya kenakalan remaja. Berbagai faktor yang ada tersebut dapat dikelompokkan menjadi faktor internal dan faktor eksternal. Berikut ini penjelasannya secara ringkas:

1. Faktor Internal

a. Krisis identitas

Perubahan biologis dan sosiologis pada diri remaja memungkinkan terjadinya dua bentuk integrasi. Pertama, terbentuknya perasaan akan konsistensi dalam kehidupannya. Kedua, tercapainya identitas peran. Kenakalan remaja terjadi karena remaja gagal mencapai masa integrasi kedua.

b. Kontrol diri yang lemah

Remaja yang tidak bisa mempelajari dan membedakan tingkah laku yang dapat diterima dengan yang tidak dapat 
diterima akan terseret pada perilaku 'nakal'. Begitupun bagi mereka yang telah mengetahui perbedaan dua tingkah laku tersebut, namun tidak bisa mengembangkan kontrol diri untuk bertingkah laku sesuai dengan pengetahuannya.

2. Faktor Eksternal

a. Kurangnya perhatian dari orang tua, serta kurangnya kasih sayang

Keluarga adalah merupakan lembaga pendidikan yang pertama dan merupakan dasar fundamental bagi perkembangan dan pertumbuhan kepribadian anak. Oleh karena itu keluarga mempunyai peranan penting dalam memberikan gerak atau warna bagi pembentukan kepribadian anak. Lingkungan keluarga ada bermacammacam keadaannya dan sarana potensi dapat memberikan pengaruh yang positif maupun negative.

Keluarga merupakan unit social terkecil yang memberikan fondasi primer bagi perkembangan anak. Sedangkan lingkungan sekitar dan sekolah ikut memberikan nuansa pada perkembangan anak. Karena itu baikburuknya struktur keluarga dan masyarakat sekitar memberikan pengaruh baik atau buruknya pertumbuhan kepribadian anak

Keadaan lingkungan keluarga yang menjadi sebab timbulnya kenakalan remaja seperti keluarga yang brokenhome, rumah tangga yang berantakan disebabkan oleh kematian ayah atau ibunya, keluarga yang diliputi konflik keras, ekonomi keluarga yang kurang, semua itu merupakan sumber yang subur untuk memunculkan delinkuensi remaja. Dr. Kartini Kartono juga berpendapat bahwasannya faktor penyebab terjadinya kenakalan remaja antara lain:

1. Anak kurang mendapatkan perhatian, kasih sayang dan tuntunan pendidikan orang tua, terutama bimbingan ayah, karena ayah dan ibunya masing-masing sibuk mengurusi permasalahan serta konflik batin sendiri Karena kurang mendapat kasih sayang dan perhatian orang tua, yang amat dibutuhkannya itu terpaksa dicari di luar rumah, seperti di dalam kelompok kawan kawannya.

2. Kebutuhan fisik maupun psikis anak-anak remaja yang tidak terpenuhi, keinginan dan harapan anak-anak tidak bisa tersalur dengan memuaskan, atau tidak mendapatkan kompensasinya

3. Anak tidak pernah mendapatkan latihan fisik dan mental yang sangat diperlukan untuk hidup normal, mereka tidak dibiasakan dengan disiplin dan kontrol-diri yang baik. Maka dengan demikian perhatian dan kasih sayang dari orang tua merupakan suatu dorongan yang berpengaruh dalam kejiwaan seorang remaja dalam membentuk kepribadian serta sikap remaja sehari-hari. Jadi perhatian dan kasih sayang dari orang tua merupakan faktor penyebab terjadinya kenakalan remaja.

b. Minimnya pemahaman tentang keagamaan

Dalam kehidupan berkeluarga, kurangnya pembinaan agama juga menjadi salah satu faktor terjadinya kenakalan remaja. Dalam pembinaan moral, agama mempunyai peranan yang sangat penting karena nilai-nilai moral yang datangnya dari agama tetap tidak berubah karena perubahan waktu dan tempat.

Pembinaan moral ataupun agama bagi remaja melalui rumah tangga perlu dilakukan

sejak kecil sesuai dengan umurnya karena setiap anak yang dilahirkan belum mengerti mana yang benar dan mana yang salah, juga belum mengerti mana batas-batas ketentuan moral dalam lingkungannya. Karena itu 
pembinaan moral pada permulaannya dilakukan di rumah tangga dengan latihan - latihan, nasehat-nasehat yang dipandang baik. Maka pembinaan moral harus dimulai dari orang tua melalui teladan yang baik berupa hal-hal yang mengarah kepada perbuatan positif, karena apa yang diperoleh dalam rumah tangga remaja akan dibawa ke lingkungan masyarakat. Oleh karena itu pembinaan moral dan agama dalam keluarga penting sekali bagi remaja untuk menyelamatkan mereka dari kenakalan dan merupakan cara untuk mempersiapkan hari depan generasi yang akan datang, sebab kesalahan dalam pembinaan moral akan berakibat negatif terhadap remaja itu sendiri. Pemahaman tentang agama sebaiknya dilakukan semenjak kecil, yaitu melalui kedua orang tua dengan cara memberikan pembinaa moral dan bimbingan tentang keagamaan, karena bimbingan keagamaan merupakan daya unsur utama untuk menangkal akibat negatif dalam kehidupan masyarakat. Pembinaan keagamaan merupakan salah satu daya tangkal yang dapat menolak pengaruh negatif terhadap seseorang, oleh karenanya sejak dini kita tanamkan pendidikan agama kepada anak agar nantinya setelah mereka remaja bisa memilah baik buruk perbuatan yang ingin mereka lakukan sesuatu di setiap harinya.

Kondisi masyarakat sekarang yang sudah begitu mengagungkan ilmu pengetahuan mengakibatkan kaidahkaidah moral dan tata susila yang dipegang teguh oleh orangorang dahulu menjadi tertinggal di belakang. Dalam masyarakat yang telah terlalu jauh dari agama, kemerosotan moral orang dewasa sudah lumrah terjadi. Kemerosotan moral, tingkah laku dan perbuatan - perbuatan orang dewasa yang tidak baik menjadi contoh atau tauladan bagi anak-anak dan remaja sehingga berdampak timbulnya kenakalan remaja.
Karena itu menurut hemat penulis faktor religius bangsa betul - betul dibutuhkan sebagai landasan etik dalam membina remaja, karena pendidikan agama merupakan unsur utama untuk menangkal akibat negatif dalam kehidupan masyarakat. Pembinaan agama merupakan salah satu daya tangkal yang dapat menolak pengaruh negatif terhadap seseorang.

Mengingat begitu pentingnya sentuhan keagamaan dalam membina moral bangsa, maka pemerintah mengaturnya dalam Undang - undang no. 2 thn 1989

"Pendidikan keagamaan bertujuan untuk ikut serta mencerdaskan kehidupan bangsa dan mengembanngkan manusia seutuhnya, yaitu manusia beragama yang beriman dan bertakwa kepada tuhan yang maha esa dan berbudi luhur, serta memiliki pengetahuan yang mendalam dan ketrampilan tentang agamanya. Sehat jasmani dan rohani, berkepribadian serta mandiri serta memiliki rasa tanggung jawab kemasyarakatan dan tanggung jawab"

c. Pengaruh dari lingkungan sekitar,

Memang dunia moderen telah membawa umat manusia pada era kemajuan, namun disatu sisi telah mengubah tatan masyarakat kita termasuk moral generasi muda dan anak - anak, imbas negatif ini terlihat pada kerusakan akhlak mereka mulai dari yang tergolong ringan sampai yanng berat, seperti perkelahian, perampokan dan tindakan kriminal lainnya. Kemerosotan akhlak ini telah mengancam sebagian generasi kita dan merupakan problem yang sangat serius bagi para orang tua.

Harus diakui dahsatnya serbuan budaya barat mampu menjauhkan para remaja dari masjid dan majelis pengajian. Dampak negara kita banyak dibanjiri remaja yang kehilangan jati dirinya. Kerusakan bukan hanya pada pemikiran tapi juga perilaku, maka 
muncullah ritual semacam dugem, party, weekend dan sejenisnya, tidak hanya itu praktek kekerasan dan kriminalitas juga menggejala. Fenomena tersebut melahirkan problem sosial yang kadang meresahkan masyarakat sehingga terbitlah sebutan remaja nakal atau bahkan sampah masyarakat.

Pengaruh budaya barat serta pergaulan dengan teman sebayanya yang sering mempengaruhinya untuk mencoba dan akhirnya malah terjerumus ke dalamnya. Lingkungan adalah faktor yang paling mempengaruhi perilaku dan watak remaja. Jika dia hidup dan berkembang di lingkungan yang buruk, moralnya pun akan seperti itu adanya. Sebaliknya jika ia berada di lingkungan yang baik maka ia akan menjadi baik pula. Di dalam kehidupan bermasyarakat, remaja sering melakukan keonaran dan mengganggu ketentraman masyarakat karena terpengaruh dengan budaya barat atau pergaulan dengan teman sebayanya yang sering mempengaruhi untuk mencoba. Sebagaimana diketahui bahwa para remaja umumnya sangat senang dengan gaya hidup yang baru tanpa melihat faktor negatifnya, karena anggapan ketinggalan zaman jika tidak mengikutinya

\section{d. Tempat pendidikan}

Tempat pendidikan, dalam hal ini yang lebih spesifiknya adalah berupa lembaga pendidikan atau sekolah. Kenakalan remaja ini sering terjadi ketika anak berada di sekolah dan jam pelajaran yang kosong. Belum lama ini bahkan kita telah melihat dimedia adanya kekerasan antar pelajar yang terjadi di sekolahnya sendiri. Ini adalah bukti bahwa sekolah juga bertanggung jawab atas kenakalan dan dekadensi moral yang terjadi di negeri ini. Untuk itu Sebagai ujung tombak dalam pendidikan anak, sekolah memiliki peran sangat vital dalam menyelesaikan problematika kenakalan remaja. Oleh karena itu, sekolah dengan struktur dan manajemen profesinalnya sudah seharusnya mengalokasikan sumber daya manusia dan finansialnya agar tetap aktif dalam menangani kenakalan remaja. Ada empat langkah praktis yang sangat memungkinkan untuk dilakukan disekolah dalam rangka mencegah dan mengatasi kenakalan remaja. Semuanya dapat dirangkum dalam empat point penting. Pertama, menguatkan pendidikan karakter yang baik kepada anak di sekolah dengan keteladanan dan menyemarakkan kegiatan kegiatan positif. Kedua, melakukan pendekatan psikologis yang humanis kepada anak melalui bimbingan dan konseling. Ketiga, menguatkan kerja sama antara sekolah, orang tua, dan lingkungan dalam mengontrol perkembangan karakter anak. Keempat, menegakkan tata tertib sekolah secara disiplin.

Akibat-akibat yang ditimbulkan oleh kenakalan remaja antara lain:

1. Bagi diri remaja itu sendiri

Akibat dari kenakalan yang dilakukan oleh remaja akan berdampak bagi dirinya sendiri dan sangat merugikan baik fisik dan mental, walaupun perbuatan itu dapat memberikan suatu kenikmatan akan tetapi itu semua hanya kenikmatan sesaat saja. Dampak bagi fisik yaitu seringnya terserang berbagai penyakit karena gaya hidup yang tidak teratur. Sedangkan dampak bagi mental yaitu kenakalan remaja tersebut akan mengantarnya kepada mental-mental yang lembek, berfikir tidak stabil dan kepribadiannya akan terus menyimpang dari segi moral yang pada akhirnya akan menyalahi aturan etika dan estetika. Dan hal itu akan terus berlangsung selama remaja tersebut tidak memiliki orang yang membimbing dan mengarahkan.

2. Bagi keluarga

Anak merupakan penerus keluarga yang nantinya dapat menjadi 
tulang punggung keluarga apabila orang tuanya tidak mampu lagi bekerja. Apabila remaja selaku anak dalam keluarga berkelakuan menyimpang dari ajaran agama, akan berakibat terjadi ketidakharmonisan di dalam kekuarga dan

putusnya komunikasi antara orang tua dan anak. Tentunya hal ini sangat tidak baik karena dapat mengakibatkan remaja sering keluar malam dan jarang pulang serta menghabiskan waktunya bersama teman-temannya untuk bersenang-senang dengan jalan minum-minuman keras atau mengkonsumsi narkoba. Pada akhirnya keluarga akan merasa malu dan kecewa atas apa yang telah dilakukan oleh remaja. Padahal kesemuanya itu dilakukan remaja hanya untuk melampiaskan rasa kekecewaannya terhadap apa yang terjadi dalam keluarganya.

3. Bagi lingkungan masyarakat

Apabila remaja berbuat kesalahan dalam kehidupan masyarakat, dampaknya akan buruk bagi dirinya dan keluarga. Masyarakat akan menganggap bahwa remaja itu adalah tipe orang yang sering membuat keonaran, mabuk-mabukan atau pun mengganggu ketentraman masyarakat. Mereka dianggap anggota masyarakat yang memiliki moral rusak, dan pandangan masyarakat tentang sikap remaja tersebut akan jelek. Adanya kenakalan remaja bukan berarti tanpa sebab, kenakalan-kenakalan tersebut timbul karena adanya faktorfaktor yang mendasarinya. Banyak faktor yang menjadi penyebab kenakalan remaja. Faktor-faktor itu antara lain berasal dari factor diri sendiri, rumah tangga/keluarga, masyarakat, dan juga sekolah. Untuk merubah semuanya menjadi normal kembali membutuhkan waktu yang lama dan hati yang penuh keikhlasan.

\section{Solusi Kenakalan Remaja}

Dari berbagai faktor dan permasalahan yang terjadi di kalangan remaja masa kini sebagaimana telah disebutkan di atas, maka tentunya ada beberapa solusi yang tepat dalam pembinaan dan perbaikan remaja masa kini. Kenakalan remaja dalam bentuk apapun mempunyai akibat yang negatif baik bagi masyarakat umum maupun bagi diri remaja itu sendiri. Tindakan penanggulangan kenakalan remaja dapat dibagi dalam:

1. Tindakan Preventif

Usaha pencegahan timbulnya kenakalan remaja secara umum dapat dilakukan melalui cara berikut:

- Mengenal dan mengetahui ciri umum dan khas remaja

- Mengetahui kesulitan kesulitan yang secara umum dialami oleh para remaja. Kesulitan kesulitan mana saja yang biasanya menjadi sebab timbulnya pelampiasandalam bentuk kenakalan.

Usaha pembinaan remaja dapat dilakukan dengan cara :

- Menguatkan sikap mental remaja supaya mampu menyelesaikan persoalan yanng dihadapinya.

- Memberikan pendidikan bukan hanya dalam penambahan pengetahuan dan keterampilan melainkan pendidikan mental dan pribadi melalui pengajaran agama, budi pekerti dan etiket.

- Menyediakan sarana sarana dan menciptakan suasana yang optimal demi perkembangan pribadi yang wajar

- Memberikan wejangan secara umum dengan harapan dapat bermanfaat.

- Memperkuat motivasi atau dorongan untuk bertingkah laku baik dan merangsang hubungan sosial yang baik

- Mengadakan kelompok diskusi dengan memberikan kesempatan mengemukakan pandangan dan pendapat para remaja dan memberikan pengarahan yang positif

- Memperbaiki keadaan lingkungan sekitar, keadaan sosial keluarga maupun masyarakat di mana banyak terjadi kenakalan remaja. 
Sebagaimana disebut di atas, bahwa keluarga juga mempunyai andil dalam membentuk pribadi seorang remaja. Jadi untuk memulai perbaikan, maka harus mulai dari diri sendiri dan keluarga. Mulailah perbaikan dari sikap yang paling sederhana, seperti selalu berkata jujur meski dalam gurauan, membaca doa setiap melakukan halhal kecil, memberikan bimbingan agama yang baik kepada anak dan masih banyak hal lagi yang bisa dilakukan oleh keluarga. Memang tidak mudah melakukan dan membentuk keluarga yang baik, tetapi semua itu bisa dilakukan dengan pembinaan yang perlahan dan sabar.

Dengan usaha pembinaan yang terarah, para remaja akan mengembangkan diri dengan baik sehingga keseimbangan diri yang serasi antara aspek rasio dan aspek emosi akan dicapai. Pikiran yang sehat akan mengarahkan para remaja kepada perbuatan yang pantas, sopan dan bertanggung jawab yang diperlukan dalam menyelesaikan kesulitan atau persoalan masing-masing.

Sekolah adalah lembaga pendidikan formal yang memiliki pengaruh kuat terhadap perkembangan remaja. Ada banyak hal yang bisa dilakukan pihak sekolah untuk memulai perbaikan remaja, di antaranya melakukan program "monitoring" pembinaan remaja melalui kegiatan-kegiatan keagamaan, kegiatan ekstrakurikuler yang ada di sekolah dan penyelenggaraan berbagai kegiatan positif bagi remaja

Pemberian bimbingan terhadap remaja tersebut bertujuan menambah pengertian remaja mengenai:

- Pengenalan diri sendiri: menilai diri sendiri dan hubungan dengan orang lain.

- Penyesuaian diri: mengenal dan menerima tuntutan dan menyesuaikan diri dengan tuntutan tersebut.

- Orientasi diri: mengarahkan pribadi remaja ke arah pembatasan antara diri pribadi dan sikap sosial dengan penekanan pada penyadaran nilai-nilai sosial, moral dan etik.

Bimbingan yang dilakukan terhadap remaja dilakukan dengan dua pendekatan:
- Pendekatan langsung, yakni bimbingan yang diberikan secara pribadi pada remaja itu sendiri. Melalui percakapan mengungkapkan kesulitan remaja dan membantu mengatasinya.

- Pendekatan melalui kelompok, di mana ia sudah merupakan anggota kumpulan atau kelompok kecil tersebut

2. Tindakan Represif

Usaha menindak pelanggaran normanorma sosial dan moral dapat dilakukan dengan mengadakan hukuman terhadap setiap perbuatan pelanggaran. Dengan adanya sanksi tegas pelaku kenakalan remaja tersebut, diharapkan agar nantinya si pelaku tersebut "jera" dan tidak berbuat hal yang menyimpang lagi. Oleh karena itu, tindak lanjut

harus ditegakkan melalui pidana atau hukuman secara langsung bagi yang melakukan kriminalitas tanpa pandang bulu. Sebagai contoh, remaja harus mentaati peraturan dan tata cara yang berlaku dalam keluarga. Disamping itu perlu adanya semacam hukuman yang dibuat oleh orangtua terhadap pelanggaran tata tertib dan tata cara keluarga. Pelaksanaan tata tertib harus dilakukan dengan konsisten. Setiap pelanggaran yang sama harus dikenakan sanksi yang sama. Sedangkan hak dan kewajiban anggota keluarga mengalami perubahan sesuai dengan perkembangan dan umur. Di lingkungan sekolah, kepala sekolahlah yang berwenang dalam pelaksanan hukuman terhadap pelanggaran tata tertib sekolah. Dalam beberapa hal, guru juga berhak bertindak. Akan tetapi hukuman yang berat seperti skorsing maupun pengeluaran dari sekolah merupakan wewenang kepala sekolah. Guru dan staf pembimbing bertugas menyampaikan data mengenai pelanggaran dan kemungkinan-kemungkinan pelanggaran maupun akibatnya. Pada umumnya tindakan represif diberikan dalam bentuk memberikan peringatan secara lisan maupun tertulis kepada pelajar dan orang tua, melakukan pengawasan khusus oleh kepala sekolah dan tim guru atau pembimbing dan melarang bersekolah untuk sementara waktu (skors) 
atau seterusnya tergantung dari jenis pelanggaran tata tertib sekolah.

3. Tindakan Kuratif dan Rehabilitasi

Tindakan ini dilakukan setelah tindakan pencegahan lainnya dilaksanakan dan dianggap perlu mengubah tingkah laku pelanggar remaja itu dengan memberikan pendidikan lagi. Pendidikan diulangi melalui pembinaan secara khusus yang sering ditangani oleh suatu lembaga khusus maupun perorangan yang ahli dalam bidang ini. Solusi internal bagi seorang remaja dalam mengendalikan kenakalan remaja antara lain:

- Kegagalan mencapai identitas peran dan lemahnya kontrol diri bisa dicegah atau diatasi dengan prinsip keteladanan. Remaja harus bias mendapatkan sebanyak mungkin figure orang-orang dewasa yang telah melampaui masa remajanya dengan baik juga mereka yang berhasil memperbaiki diri setelah sebelumnya gagal pada tahap ini. Adanya motivasi dari keluarga, guru, teman sebaya untuk melakukan point pertama.

- Remaja menyalurkan energinya dalam berbagai kegiatan positif, seperti berolahraga, melukis, mengikuti event perlombaan, dan penyaluran hobi.

- Remaja pandai memilih teman dan lingkungan yang baik serta orangtua memberi arahan dengan siapa dan di komunitas mana remaja harus bergaul.

- Remaja membentuk ketahanan diri agar tidak mudah terpengaruh jika ternyata teman sebaya atau komunitas yang ada tidak sesuai dengan harapan. Jika berbagai solusi dan pembinaan di atas dilakukan, diharapkan kemungkinan terjadinya kenakalan remaja ini akan semakin berkurang dan teratasi. Dari pembahasan mengenai penanggulangan masalah kenakalan remaja ini perlu ditekankan bahwa segala usaha pengendalian kenakalan remaja harus ditujukan ke arah tercapainya kepribadian remaja yang mantap, serasi dan dewasa. Remaja diharapkan akan menjadi orang dewasa yang berpribadi kuat, sehat jasmani dan rohani, teguh dalam kepercayaan (iman) sebagai anggota masyarakat, bangsa dan tanah air.

\section{SIMPULAN}

Masalah kenakalan remaja mulai mendapat perhatian masyarakat secara khusus sejak terbentuknya peradilan untuk anak-anak nakal (juvenile court) pada 1899 di Illinois, Amerika Serikat. Kenakalan remaja meliputi semua perilaku yang menyimpang dari normanorma hukum pidana yang dilakukan oleh remaja. Perilaku tersebut akan merugikan dirinya sendiri dan orang-orang di sekitarnya. Faktor yang melatar belakangi terjadinya kenakalan remaja dapat dikelompokkan menjadi faktor internal dan faktor eksternal. Faktor internal berupa krisis identitas dan kontrol diri yang lemah. Sedangkan faktor eksternal berupa kurangnya perhatian dari orang tua; minimnya pemahaman tentang keagamaan; pengaruh dari lingkungan sekitar dan pengaruh budaya barat serta pergaulan dengan teman sebaya; dan tempat pendidikan. Akibat-akibat yang ditimbulkan oleh kenakalan remaja akan berdampak kepada diri remaja itu sendiri, keluarga, dan lingkungan masyarakat. Solusi dalam menanggulangi kenakalan remaja dapat dibagi ke dalam tindakan preventif, tindakan represif, dan tindakan kuratif dan rehabilitasi. Adapun solusi internal bagi seorang remaja dalam mengendalikan kenakalan remaja antara lain:

- Kegagalan mencapai identitas peran dan lemahnya kontrol diri bisa dicegah atau diatasi dengan prinsip keteladanan

- Adanya motivasi dari keluarga, guru, teman sebaya untuk melakukan point pertama

- Remaja menyalurkan energinya dalam berbagai kegiatan positif

- Remaja pandai memilih teman dan lingkungan yang baik serta orangtua memberi arahan dengan siapa dan di komunitas mana remaja harus bergaul,

- Remaja membentuk ketahanan diri agar tidak mudah terpengaruh jika ternyata teman sebaya atau komunitas yang ada tidak sesuai dengan harapan Segala usaha pengendalian kenakalan remaja harus ditujukan ke arah tercapainya kepribadian remaja yang mantap, serasi dan 
dewasa. Remaja diharapkan akan menjadi orang dewasa yang berpribadi kuat, sehat jasmani dan rohani, teguh dalam kepercayaan (iman) sebagai anggota masyarakat, bangsa dan tanah air.

\section{DAFTAR PUSTAKA}

Bimo Walgito, Kenakalan Anak, (Yogyakarta:

Yayasan Penerbitan Fakultas Psikologi, 1982).

Fuad Kauma, Sensasi Remaja di Masa Puber (Dampak Negatif dan Upaya Penanggulangannya), (Jakarta, Kalam Mulia, 1999).

Kartini Kartono, Kenakalan Remaja, (Jakarta: PT. Raja Grafindo Persada, 1998).

Raharjo, ST. 2015. Assessment untuk Praktik Pekerjaan Sosial dan Kesejahteraan Sosial. Bandung: Unpad Press

— 2015. Dasar Pengetahuan Pekerjaan Sosial. Bandung: Unpad Press.

, 2015. Keterampilan Pekerjaan Sosial: Dasar-dasar. Bandung, Unpad Press.

Willis, Sofyan. (2012). Remaja dan Masalahnya. Bandung: Alfabeta

Sarwono, Sarlito. (2012). Psikilogi Remaja. Jakarta: Rajawali Press. 